\title{
Photoacclimation of Stylophora pistillata to light extremes: metabolism and calcification
}

\author{
Tali Mass ${ }^{1,2, *}$, Shai Einbinder ${ }^{1,3,4}$, Eran Brokovich ${ }^{1,3}$, Nadav Shashar ${ }^{1,5}$, $\operatorname{Razi}_{\operatorname{Vago}^{6}}$, \\ Jonathan Erez ${ }^{7}$ Zvy Dubinsky ${ }^{2}$ \\ ${ }^{1}$ The Interuniversity Institute for Marine Sciences at Eilat, PO Box 469, Eilat 88103, Israel \\ ${ }^{2}$ The Mina \& Everard Goodman Faculty of Life Sciences, Bar-Ilan University, Ramat-Gan 52900, Israel \\ ${ }^{3}$ Evolution Systematics and Ecology Department, Life Sciences Institute, The Hebrew University of Jerusalem, \\ Jerusalem 91904, Israel \\ ${ }^{4}$ Israel Maritime College, Ruppin Academic Center, Michmoret 40297, Israel \\ ${ }^{5}$ Department of Life Sciences, Ben Gurion University of the Negev, Beer Sheva 84105, Israel \\ ${ }^{6}$ Department of Biotechnology Engineering, Ben Gurion University of the Negev, Beer Sheva 84105, Israel \\ ${ }^{7}$ Institute of Earth Sciences, The Hebrew University of Jerusalem, Jerusalem 91904, Israel
}

\begin{abstract}
The hermatypic coral Stylophora pistillata has a wide bathymetric distribution $(0$ to $70 \mathrm{~m}$ ). Within this range, light intensity decreases exponentially. Deep-water colonies are generally planar in morphology, with the upper part being dark and the bottom-facing part pale. Shallow-water colonies are generally subspherical and ivory in coloration. We studied the effects of photoacclimation on photosynthesis, respiration, and calcification in S. pistillata colonies along its bathymetric range over a reef profile (5 to $65 \mathrm{~m}$ ) in Eilat, Gulf of Aqaba, Red Sea, during winter and summer, using a submersible respirometer. Respiration rate, light-saturated rate of photosynthesis $\left(P_{\max }\right)$, compensation light intensity $\left(E_{\mathrm{c}}\right)$, and light intensity of incipient saturation $\left(E_{\mathrm{k}}\right)$, all decreased with depth. In contrast, the efficiency of photosynthesis $(\alpha)$ increased with depth. All colonies displayed 'lightenhanced calcification' during daytime and decreasing calcification rates with depth. These results indicate an adjustment in harvesting and utilization of light by the algal symbionts to the light environment. At all light intensities except the lowest ones, there was a consistent ratio of calcification to photosynthesis, in agreement with the concept of light-enhanced calcification. In the deepest, lowlight corals, there was no evidence for support of calcification by photosynthesis, and we assume that these colonies subsist mainly by preying on zooplankton.
\end{abstract}

KEY WORDS: Photosynthesis · Calcification $\cdot$ Dissolved oxygen $\cdot \mathrm{pH} \cdot$ Total alkalinity $\cdot$ Stylophora pistillata $\cdot$ Deep coral reef

\section{INTRODUCTION}

Scleractinian corals are characterized by the presence of a large population of endocellular symbiotic dinoflagellates, mostly of the genus Symbiodinium (Masuda et al. 1993), commonly referred to as zooxanthellae (Brandt 1883). Initially, all zooxanthellae were thought to belong to the species $S$. microadriaticum (Freudenthal 1962); however, work by Trench \& Blank (1987) showed that zooxanthellate coelenterates har- bor more than one species of dinoflagellate symbionts. More recently, with the advent of biological molecular tools, even these taxa were found to consist of many 'clades' (Rowan 1998).

The photosynthesis of the zooxanthellae makes a major contribution to the energy requirements of reef corals (Muscatine 1990). Thus, light, the intensity of which decreases exponentially with depth, is a major factor affecting the vertical distribution of corals in the photic zone (Wells 1957, Dubinsky et al. 1984). Coral 
species that have a wide vertical distribution, where light intensity spans more than 2 orders of magnitude, exhibit various photoacclimation responses (Falkowski \& Dubinsky 1981).

In shallow, well-lit environments, the zooxanthellae provide their host corals with most of the metabolic energy they require (Falkowski \& Dubinsky 1981), including that needed for calcification (Goreau 1959). The dependence of calcification rate on light energy has been experimentally demonstrated for a number of coral species and is further shown by the confinement of reef-building corals to the photic zone (Wells 1957 , Dubinsky et al. 1984).

The photoacclimation of corals to light intensity involves phenotypic responses of both host and symbionts (Bruno \& Edmunds 1997). Theoretically, the increase in either the algal density (Titlyanov et al. 2001) or the pigmentation of each algal cell (Falkowski \& Dubinsky 1981 ) is expected to increase light absorption, which is advantageous under low light (Dubinsky et al. 1984). Under the very high light intensities common in the tropics on shallow reef tables, the opposite is true, since excess irradiance inhibits photosynthesis and generates harmful free radicals (Erez 1978, Levy et al. 2006).

Photoacclimative changes in the photosynthetic apparatus of zooxanthellae within coral tissues produce profound changes in the photosynthesis-versusirradiance relationship (often presented in $P-E$ curves) in corals growing under different light regimes (Falkowski \& Dubinsky 1981). These acclimation responses can be described by several generalizations: the initial slopes of the $P-E$ curves $(\alpha)$ and the respiration rate $(R)$ decrease with decreasing irradiance (Falkowski \& Dubinsky 1981). The irradiance at the initial slope of the curve that intersects the horizontal asymptote $\left(E_{\mathrm{k}}\right)$, the compensation intensity irradiance $\left(E_{\mathrm{c}}\right)$, which is the irradiance at which the rates of gross photosynthesis and respiration are equal, and the maximum gross rate of photosynthesis $\left(P_{\max }\right)$ when expressed in terms of chl a content (the assimilation number), all decrease with increasing irradiance (Falkowski \& Dubinsky 1981)

Concomitantly, changes also take place in the animal host. Under dim light, coral colonies tend toward a spread-out, 2-dimensional architecture, maximizing light harvesting and avoiding intra-colony shading. In branching species, branches are thin and arranged horizontally, rather than subspherically. Spherical species become flattened out, or encrusting. Under light constraints and limited photosynthesis, dark respiration and growth are slower than in high-light conditions (Dubinsky et al. 1990).

Photosynthesis, respiration, and calcification of marine organisms affect seawater concentrations of oxygen, $\mathrm{pH}$, and the ionic species of the carbonate sys- tem (Smith \& Key 1975). Therefore, these changes can be used to estimate the rates of the metabolic processes. Photosynthesis and respiration rates are readily calculated from changes in oxygen fluxes near the coral. The rate of calcification/dissolution processes is usually derived indirectly from changes in total alkalinity (TA) (Smith \& Key 1975, Barnes 1983).

The aim of this research was to study photoacclimative changes in metabolism and calcification of a coral species along its whole bathymetric range. Due to Rosenfeld et al.'s (2003) finding of a change in growth rate between seasons, we decided to perform the experiments in different seasons.

Using the common Red Sea coral Stylophora pistillata, we addressed the following questions based on the study of colonies spanning the 5 to $65 \mathrm{~m}$ depth distribution of the species: (1) What is the seasonal effect (winter and summer) on calcification and photosynthesis rates at different depths? (2) How does depth affect coral photosynthesis, chl $a$, and zooxanthellae concentration in coral tissues? (3) What is the relationship of calcification to photosynthesis over a diel cycle at different seasons and depths?

\section{MATERIALS AND METHODS}

Study site and coral sampling. Corals were collected under a special permit by the Israeli Natural Parks Authority in the waters in front of the Interuniversity Institute for Marine Sciences, Eilat, Gulf of Aqaba, Red Sea $\left(29^{\circ} 30^{\prime} \mathrm{N}, 34^{\circ} 56^{\prime} \mathrm{E}\right)$ using Trimix SCUBA. All experiments were conducted using small (10 to $15 \mathrm{~cm}$ long) branches of the hermatypic coral Stylophora pistillata (Esper, 1797) collected at 5 to $65 \mathrm{~m}$. S. pistillata was chosen since it is a common, widely-distributed and extensively studied branching coral that is known as an 'opportunistic', r-strategist (Loya 1976), stresstolerant species inhabiting a range of reef environments from the shallow reef flat $(2 \mathrm{~m})$ to $70 \mathrm{~m}$ depth (Loya 1976).

Three branches from 3 different colonies were collected at each depth in summer (July) and winter (February), placed in a black bag, and carried to a shaded short-term incubation area at $5 \mathrm{~m}$ depth. Light intensity in the incubation area $(5 \mathrm{~m})$ was adjusted to match that of the source depths, namely $50 \mathrm{~m}$ and $65 \mathrm{~m}$, where irradiance was $\sim 13$ and $9 \%$, respectively, of that measured at $5 \mathrm{~m}$. This shading accounted for the overall photosynthetically active radiation (PAR) but could not correct for the changes in the light spectrum existing between deep and shallow waters. However, the corals stayed in this area for a few hours at most, including the time needed for the respirometry measurements (following section). Light measurements were 
conducted with a profiler reflectance radiometer (PRR600, Biospherical Instruments).

Measurements of photosynthesis and dark respiration. A submersible respirometer (Australian Institute of Marine Science, AIMS) was used for oxygen-based respirometry measurements (3 replicates per depth per season) in situ, from which $P-E$ response curves were constructed (Levy et al. 2004). The respirometer consisted of 3 chambers constructed from UV-transparent material; each chamber was equipped with an oxygen sensor (Kent EIL galvanic type ABB), a pH sensor (radiometer combination electrode type), a stirrer, and ports for sampling water. In addition, the respirometer had a light sensor (Li-Cor $4 \pi$ underwater quantum light sensor), a temperature probe, and a data logger. A centrifugal pump flushed the water in the chambers at programmable intervals. We routinely used $60 \mathrm{~min}$ intervals in the experiments to allow for the accumulation of detectable changes in oxygen. Such relatively long intervals between flushes were required since the coral volume was small $(\sim 30 \mathrm{ml})$ compared to the chamber volume $(1500 \mathrm{ml})$. The respirometer was deployed at a $5 \mathrm{~m}$ depth. Data obtained were processed using the AIMS 'Respiro' program for calibration, data handling, and analysis (Levy et al. 2004).

Respiration was measured as oxygen uptake during the dark period and was assumed to remain constant. Based on the $P-E$ curves generated using non-linear curve-fitting and theoretical models of a hyperbolic tangent equation (Ben-Zion \& Dubinsky 1988), we calculated parameters such as $\alpha$ (the light-limited initial slope), $P_{\max }$ (the light-saturated rate of photosynthesis), $E_{\mathrm{c}}$ (compensation light intensity), $E_{\mathrm{k}}$ (light of incipient saturation), and $R$ (dark respiration).

$P-E$ curve parameters were normalized to colony surface area. For surface area measurements, we divided the fragments into cylindrical parts, then measured the diameter and height of each fragment and, assuming they were cylinders, calculated the surface area.

Daily rates of net photosynthesis $\left(P_{\mathrm{nD}}\right)$, also normalized to surface area, were obtained by integrating the $24 \mathrm{~h}$ oxygen measurements.

Alkalinity. Calcification was estimated from changes in total alkalinity (TA), which were calculated from measured $\mathrm{pH}$ and oxygen ( 3 replicates per depth per season), using the alkalinity anomaly technique (Barnes 1983). This technique utilizes the fact that photosynthetic $\mathrm{CO}_{2}$ uptake (which is estimated from oxygen changes) does not change the alkalinity (but affects the $\mathrm{pH}$ ), while calcification affects both $\mathrm{pH}$ and alkalinity. In order to estimate calcification using this technique, the community photosynthetic quotient (PQ) and the community respiration quotient (RQ) need to be estimated; this can be achieved from direct measurements of alkalinity, as described below. To cali- brate the $\mathrm{pH}$ electrodes and to verify the $\mathrm{PQ}$ and $\mathrm{RQ}$ needed for estimating in situ calcification measurements using the $\mathrm{pH}$ and oxygen data, samples of $100 \mathrm{ml}$ of seawater were obtained from each of the 3 respirometer chambers for alkalinity determination every $2 \mathrm{~h}$. A volume of $15 \mathrm{ml}$ of sea water was filtered through a $0.2 \mu \mathrm{m}$ filter, weighed, and used for each analysis with an automatic titrator (Mettler DL67). For each sample, alkalinity was measured in duplicates. The calcification rates (Cal, $\mu \mathrm{mol} \mathrm{CaCO}_{3} \mathrm{~h}^{-1} \mathrm{~cm}^{-2}$ of coral) were then calculated using Eqs. (1) \& (2):

$$
\begin{gathered}
\Delta A l k=A l k_{\mathrm{f}}-A l k_{\mathrm{i}} \\
C a l=\frac{\frac{\Delta A l k}{2} \times\left(V_{\text {chamber }}-V_{\text {coral }}\right)}{T \times A_{\text {coral }}}
\end{gathered}
$$

where $A l k_{\mathrm{f}}\left(\mathrm{meq} \mathrm{kg}{ }^{-1}\right)$ is the final alkalinity, $A l k_{\mathrm{i}}$ is the initial alkalinity, $V$ is the volume of the chamber or the coral branches, and $T$ is the duration of the incubation.

Daily rates of net calcification $\left(\mathrm{Cal}_{\mathrm{nD}}\right)$ normalized to surface area were obtained from integration of the hourly rates.

Zooxanthellae isolation and pigment studies. After measuring photosynthesis and calcification rates of the intact coral, the tissue was removed by an airbrush connected to a reservoir of filtered seawater $(0.20 \mu \mathrm{m}$ filter). To correlate the absorption and biomass data, the following parameters of each coral colony were measured: colony surface area, volume of homogenate, and the concentrations of algal cells and chl a per unit volume of homogenate. From these, areal concentrations of zooxanthellae, chl $a$, and cellular chl $a$ content in zooxanthellae were calculated. Density of zooxanthellae in the homogenate was determined by microscopic counts using a hemocytometer and 10 replicate cell counts per sample.

The slurry was filtered through Whatman GF/C $(1.2 \mu \mathrm{m})$ filters ( 2 to $5 \mathrm{ml}, \mathrm{n}=3$ ), and chl $a$ was extracted in cold acetone (90\%) overnight. Chl a concentrations were determined spectrophotometrically according to the equations of Jeffrey \& Humphrey (1975), using an Ultraspec 2001 Pro (Biochrom) spectrophotometer. Based on homogenate and acetone volumes, coral area, zooxanthellae counts, $\mu \mathrm{g} \mathrm{chl} \mathrm{a} \mathrm{cm}^{-2}$ of coral, and pg chl a zooxanthella ${ }^{-1}$ were calculated.

Statistical analyses. Data were examined for homogeneity of variances (Cochran test), and if rejected, non-parametric analyses were performed (Sokal \& Rohlf 1995); 1- and 2-way ANOVA and a multiple comparison test (Tukey test) or the non-parametric Kruskal-Wallis $H$ test were used to test for differences between groups ( $p$ critical $=0.05$ in all cases). STATISTICA 6.0 (data analysis software system, StatSoft 2001) software was used. 


\section{RESULTS}

\section{Effects of light intensity on zooxanthellae}

Chl a concentration per algal cell and per coral surface area differed significantly (2-way ANOVA, $n=3$, $\mathrm{p}<0.05$ ) between both light habitats and seasons, varying from 1.8 to $3.2 \mathrm{pg}$ chl a zooxanthella ${ }^{-1}$ at $5 \mathrm{~m}$ and $65 \mathrm{~m}$, respectively, in summer and from 4.6 to $11.4 \mathrm{pg}$ chl a zooxanthella ${ }^{-1}$ at $5 \mathrm{~m}$ and $65 \mathrm{~m}$, respectively, in winter (Fig. 1). The areal densities of zooxanthellae revealed 2 trends: (1) From 5 to 15 m, density

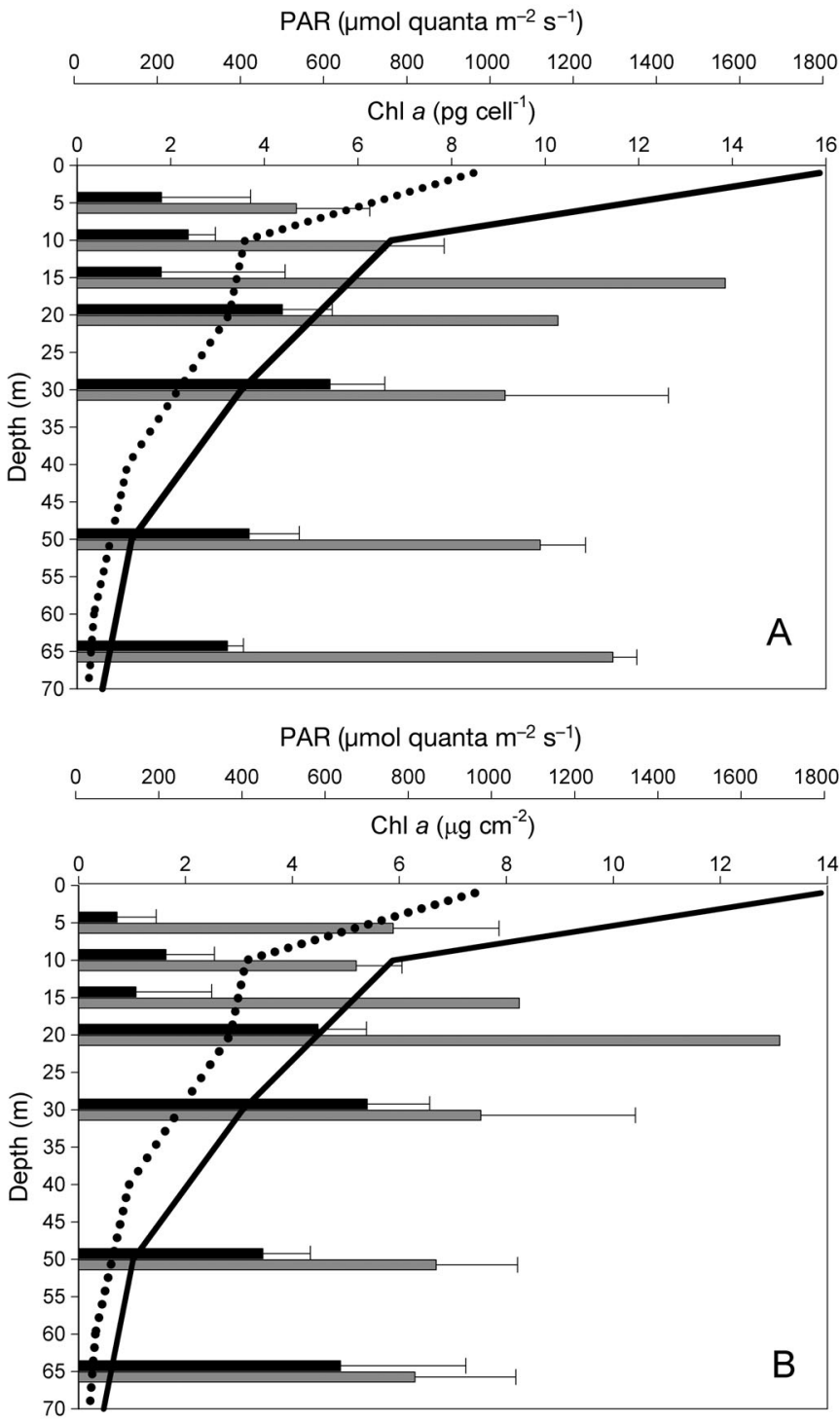

Fig. 1. Stylophora pistillata. Chl a concentration per zooxanthella (A) and per unit surface area (B) in winter (grey) and summer (black). Solid and dotted lines indicate photosynthetically active radiation (PAR) (average of samples taken between 11:00 and 13:00 $\mathrm{h}$ in the summer and winter, respectively)

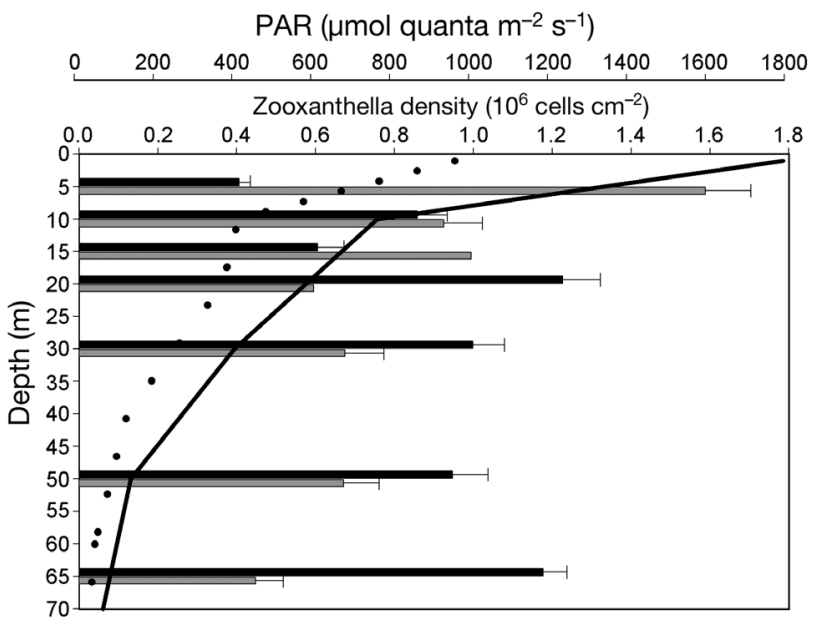

Fig. 2. Stylophora pistillata. Zooxanthella cell density per surface area in winter (grey) and summer (black). Solid and dotted lines as in Fig. 1

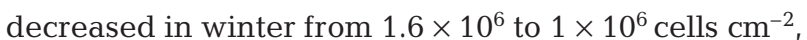
whereas in summer in that range, densities peaked at 10 m, with $8 \times 10^{5}$ cells cm ${ }^{-2}$ (Fig. 2). (2) From 20 to 65 m, density decreased in winter with depth but in summer, no clear trend was evident (2-way ANOVA, p > 0.05, Fig. 2). The highest densities $\left(1.6 \times 10^{6}\right.$ cells $\left.\mathrm{cm}^{-2}\right)$ were observed in winter at $5 \mathrm{~m}$, while in summer, high densities were found throughout the 20 to $65 \mathrm{~m}$ range.

\section{Photosynthesis and respiration}

Values of light of incipient saturation $\left(E_{\mathrm{k}}\right)$ differed significantly between depths and seasons (KruskalWallis ANOVA, $\mathrm{p}<0.05, \mathrm{n}=3$ per depth and season). Values decreased from 1084.5 (5 m) to 108.9 (65 m)

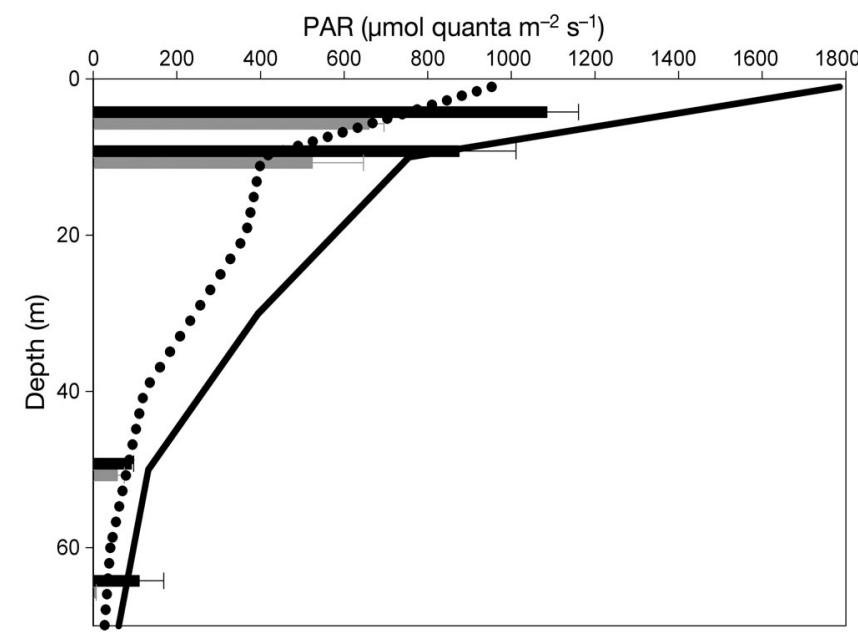

Fig. 3. Stylophora pistillata. Light of incipient saturation $\left(E_{\mathrm{k}}\right)$ in winter (grey) and summer (black). Solid and dotted lines as in Fig. 1 


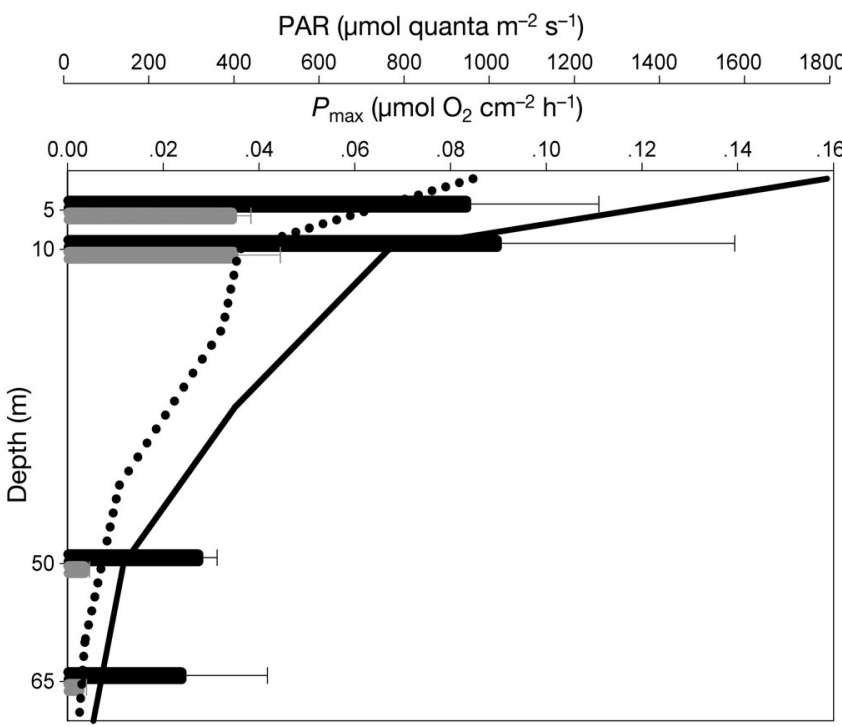

Fig. 4. Stylophora pistillata. Maximum rate of photosynthesis $\left(P_{\max }\right)$ in winter (grey) and summer (black). Solid and dotted lines as in Fig. 1

umol quanta $\mathrm{m}^{-2} \mathrm{~s}^{-1}$ in summer, and from 659.5 (5 m) to 5.8 (65 m) $\mu \mathrm{mol}$ quanta $\mathrm{m}^{-2} \mathrm{~s}^{-1}$ in winter (Fig. 3). Maximal rates of photosynthesis $\left(P_{\max }\right)$ differed significantly between light habitats and seasons (Kruskal-Wallis ANOVA, $\mathrm{p}<0.05, \mathrm{n}=3$ ). Values ranged from $0.87(5 \mathrm{~m})$ to $0.15(65 \mathrm{~m}) \mu \mathrm{mol} \mathrm{O} \mathrm{Cm}^{-2} \mathrm{~h}^{-1}$ in winter and from $1.19(5 \mathrm{~m})$ to $0.42(65 \mathrm{~m}) \mu \mathrm{mol} \mathrm{O}_{2} \mathrm{~cm}^{-2} \mathrm{~h}^{-1}$ in summer (Fig. 4). The compensation intensity $\left(E_{\mathrm{c}}\right)$ values ranged from $121.2(5 \mathrm{~m})$ to $3.1(65 \mathrm{~m}) \mu \mathrm{mol}$ quanta $\mathrm{m}^{-2} \mathrm{~s}^{-1}$ in winter and from $233.4(5 \mathrm{~m})$ to $15.4(65 \mathrm{~m})$ umol quanta $\mathrm{m}^{-2} \mathrm{~s}^{-1}$ in summer (Fig. 5).

Significant differences were also found between light habitats and seasons (2-way ANOVA, p $<0.05$,

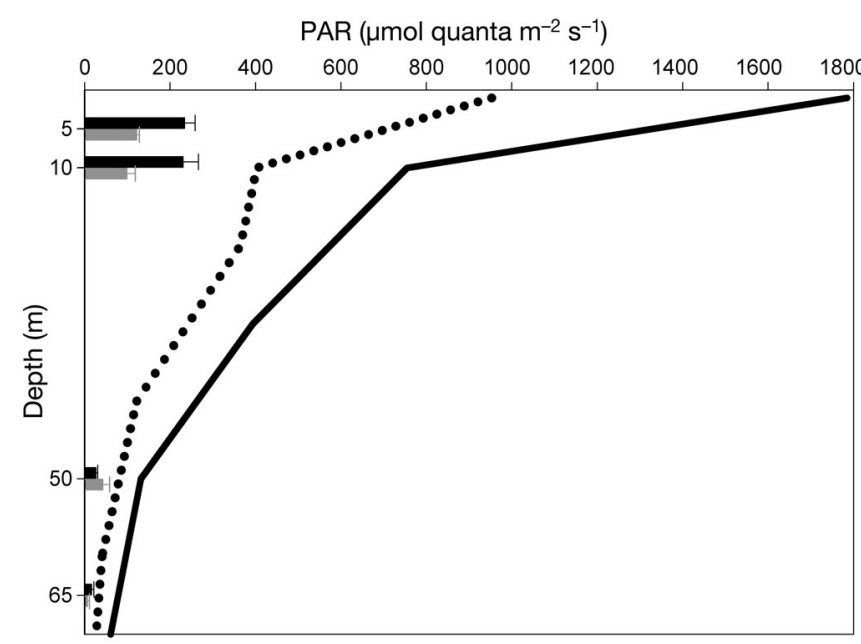

Fig. 5. Stylophora pistillata. Compensation intensity $\left(E_{\mathrm{c}}\right)$ in winter (grey) and summer (black). Solid and dotted lines as in Fig. 1

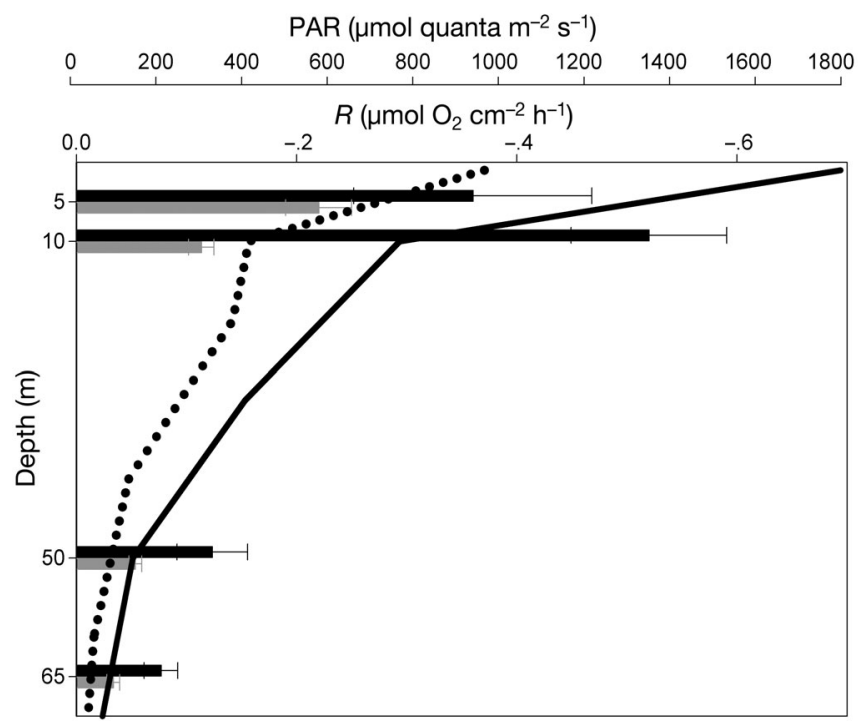

Fig. 6. Stylophora pistillata. Dark respiration $(R)$ in winter (grey) and summer (black). Solid and dotted lines as in Fig. 1

$\mathrm{n}=3)$. Respiration $(R)$ values ranged from $0.25(5 \mathrm{~m})$ to $0.04 \mu \mathrm{mol} \mathrm{O} \mathrm{Cm}^{-2} \mathrm{~h}^{-1}(65 \mathrm{~m})$ in winter and from 0.41 (5 m) to $0.08 \mu \mathrm{mol} \mathrm{O}_{2} \mathrm{~cm}^{-2} \mathrm{~h}^{-1}(65 \mathrm{~m})$ in summer (2-way ANOVA, $\mathrm{p}<0.05, \mathrm{n}=3$, Fig. 6). The apparent quantum yield ( $\alpha$, the initial slope of the $P-E$ curve) increased with depth from $5.2 \times 10^{-5}(5 \mathrm{~m})$ to $2.0 \times 10^{-4}(65 \mathrm{~m})$ $\left(\mu \mathrm{mol} \mathrm{O} \mathrm{Cm}^{-2} \mathrm{~min}^{-1} \text { ) ( } \mu \mathrm{mol} \text { quanta } \mathrm{m}^{-2} \mathrm{~s}^{-1}\right)^{-1}$ in winter and from $7.8 \times 10^{-5}(5 \mathrm{~m})$ to $1.4 \times 10^{-4}(65 \mathrm{~m})$ in summer (2-way ANOVA, $\mathrm{p}<0.05, \mathrm{n}=3$, Fig. 7).

Net photosynthesis $\left(P_{\mathrm{n}}\right)$ of corals in deep-water habitats was approximately $48 \%$ that of corals in shallow-

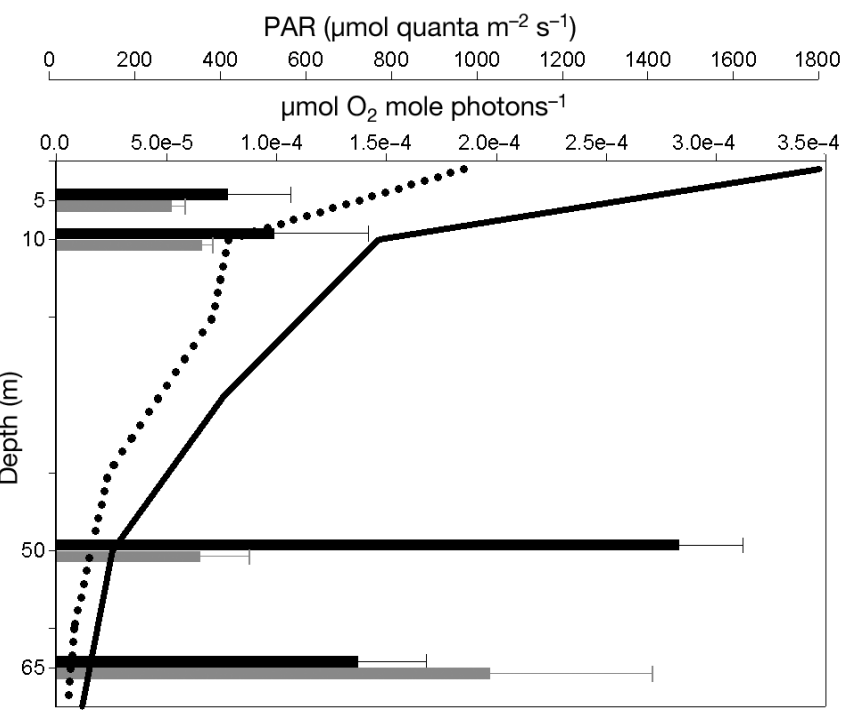

Fig. 7. Stylophora pistillata. Apparent quantum yield $(\alpha)$ in winter (grey) and summer (black). Solid and dotted lines as in Fig. 1 
water habitats in summer and only $13 \%$ in winter (Table 1). However, $P_{\mathrm{n}}$ in winter was $\sim 59 \%$ of its value in summer in the shallow habitats and $\sim 16 \%$ in the deep ones (Table 1).

Table 1. Stylophora pistillata. Hourly rate of net photosynthesis $\left(P_{\mathrm{n}}\right) \pm \mathrm{SD}$ and net calcification in daylight $\left(\mathrm{Cal}_{\mathrm{n}}\right) \pm \mathrm{SD}$, and respiration rate $(\mathrm{R})$ in the different habitats and seasons, based on $24 \mathrm{~h}$ oxygen, $\mathrm{pH}$, and irradiance records ( $\mathrm{n}=3$ per depth and per season)

\begin{tabular}{|lccc|}
\hline $\begin{array}{l}\text { Depth } \\
(\mathrm{m})\end{array}$ & $\begin{array}{c}\text { Net photosynthesis } \\
\left(\mu \mathrm{mol} \mathrm{O} \mathrm{Cm}^{-2} \mathrm{~h}^{-1}\right)\end{array}$ & $\begin{array}{c}\text { Day calcification } \\
\left(\mu \mathrm{mol} \mathrm{CaCO}_{3} \mathrm{~cm}^{-2} \mathrm{~h}^{-1}\right)\end{array}$ & $\begin{array}{c}\text { Respiration } \\
\left(\mu \mathrm{mol} \mathrm{O} \mathrm{Cm}^{-2} \mathrm{~h}^{-1}\right)\end{array}$ \\
\hline February & & & \\
5 & $0.43 \pm 0.08$ & $0.21 \pm 0.07$ & $0.25 \pm 0.03$ \\
10 & $0.27 \pm 0.12$ & $0.26 \pm 0.13$ & $0.12 \pm 0.02$ \\
50 & $0.06 \pm 0.04$ & $-0.01 \pm 0.01$ & $0.02 \pm 0.01$ \\
65 & $0.07 \pm 0.04$ & $0.06 \pm 0.04$ & $0.04 \pm 0.01$ \\
July & & & \\
5 & $0.61 \pm 0.19$ & $0.37 \pm 0.03$ & $0.41 \pm 0.12$ \\
10 & $0.67 \pm 0.18$ & $0.40 \pm 0.27$ & $0.69 \pm 0.24$ \\
50 & $0.19 \pm 0.07$ & $0.19 \pm 0.02$ & $0.11 \pm 0.04$ \\
65 & $0.30 \pm 0.25$ & $0.08 \pm 0.04$ & $0.08 \pm 0.02$ \\
\hline
\end{tabular}

Diurnal measurements of oxygen flux and $\mathrm{pH}$ using the 3-chamber submersible respirometer showed an increase in oxygen evolution with light intensity. However, peak oxygen evolution did not match the maximal light intensity, but tracked it by a $\sim 2 \mathrm{~h}$ lag (Fig. 8). This lag was most pronounced in summer at $5 \mathrm{~m}$ depth.

\section{Calcification}

In all colonies, depths, and seasons, daytime calcification rates were significantly higher than they were in darkness. In the low-light colonies (50 \& $65 \mathrm{~m})$ calcification rates were only $\sim 21 \%$ of those in the high-light (5 \& $10 \mathrm{~m}$ ) colonies in summer and $28 \%$ in winter (Fig. 9, Table 1). Likewise, calcification rates were lower in winter than in summer at all depths (Fig. 9), being only about half as fast in winter than in summer at the same depth (Table 1).
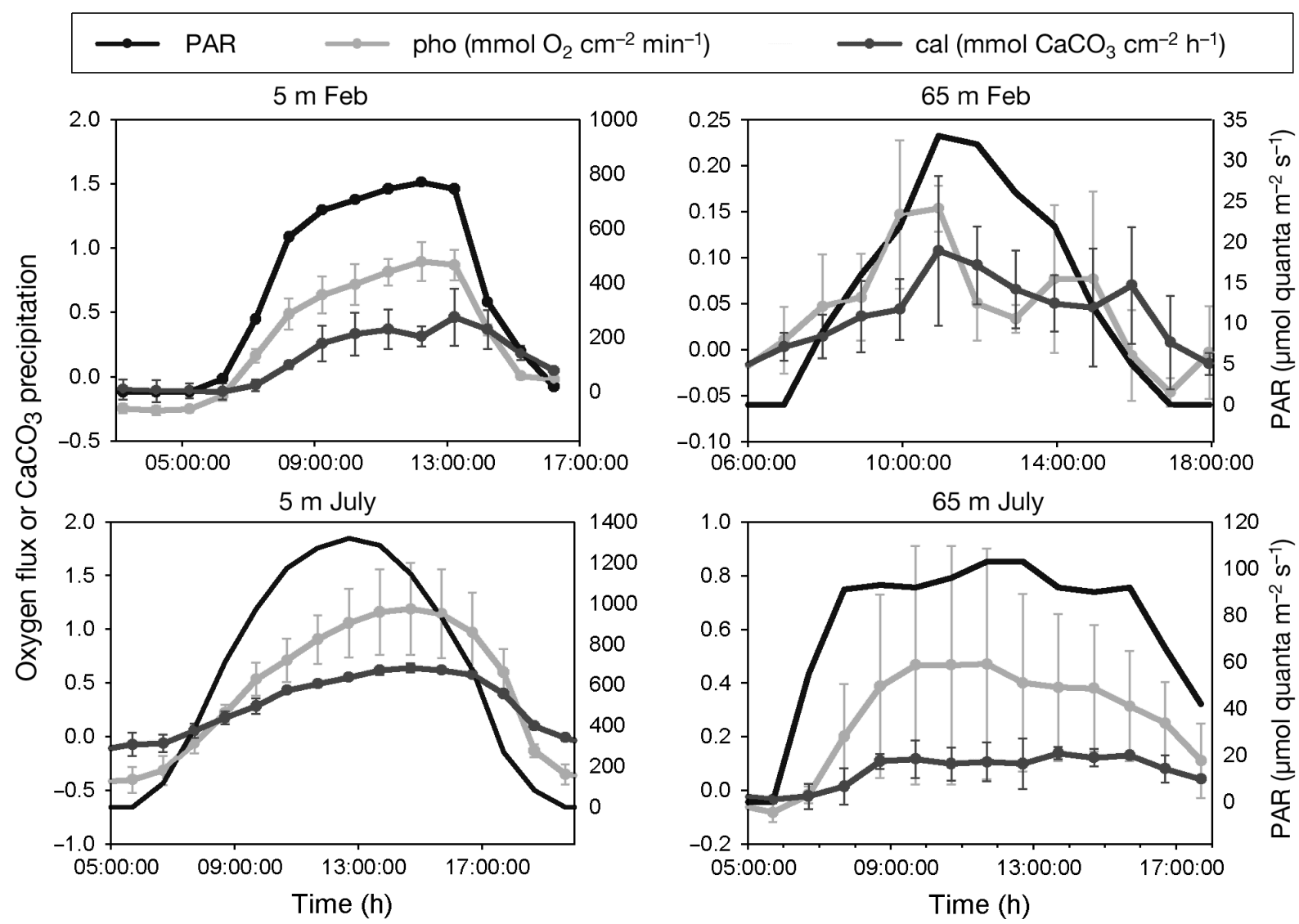

Fig. 8. Stylophora pistillata. Diel changes in downwelling light intensity and net oxygen fluxes (pho; dark grey) and net $\mathrm{CaCO}_{3}$ precipitation ( $\mathrm{cal}_{\text {; }}$ grey) in the respirometer $(\mathrm{n}=3)$ in 2 seasons and depths. Photosynthetically active radiation (PAR) is shown 


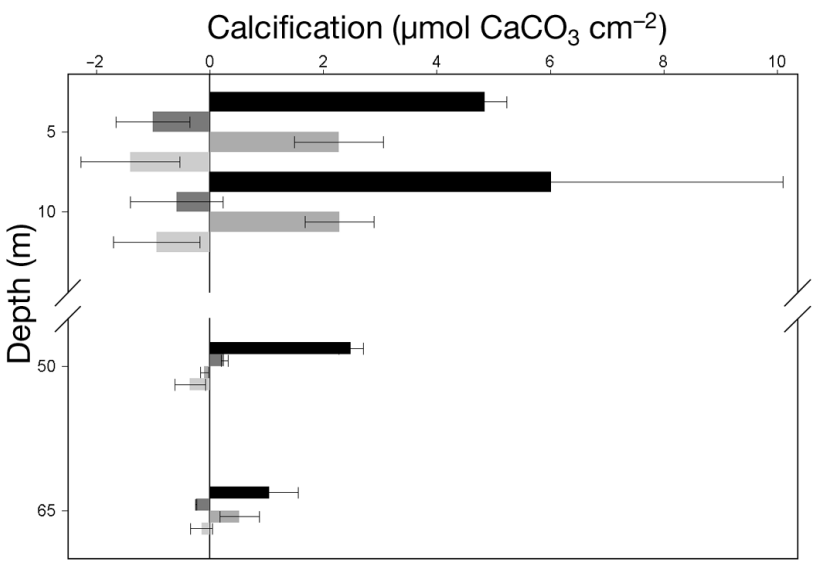

Fig. 9. Stylophora pistillata. 24 h calcification $(\mathrm{n}=3)$. Summer day (black), summer night (dark gray), winter day (medium gray), and winter night (light gray)

Calcification followed the daily course of photosynthesis with a 1:2 molar ratio $\left(\mathrm{CaCO}_{3}: \mathrm{O}_{2}\right)$ in both seasons and at all depths (Fig. 8).

\section{DISCUSSION}

The clear waters of the Gulf of Aqaba allow for deep light penetration. The depth at which light intensity is $1 \%$ of its intensity at the surface, or the euphotic depth, $\mathrm{z}_{\text {eu, }}$ varies with time of day and season, ranging from 70 to $120 \mathrm{~m}$ in winter and summer, respectively (Fricke et al. 1987, D. K. Iluz pers. comm.). In deep waters (30 to $100 \mathrm{~m}$ ), hermatypic corals face 2 major problems: lack of light and narrow wavelength spectra with a maximal intensity of approximately $475 \mathrm{~nm}$ (Fricke et al. 1987). Under such conditions, optimization of light harvesting and utilization is of paramount importance.

Photokinetic parameters of light saturation curves in shallow-water corals or isolated zooxanthellae invariably change with ambient light in ways similar to those of free-living phytoplankton (Dubinsky et al. 1986). $E_{\mathrm{C}}$ ranges between 9.7 and $350 \mu$ mol quanta $\mathrm{m}^{-2} \mathrm{~s}^{-1} ; R$, the dark respiration rate, decreases with ambient irradiance; and $E_{\mathrm{k}}$ varies between 30 and $1074 \mu \mathrm{mol}$ quanta $\mathrm{cm}^{-2} \mathrm{~s}^{-1}$ and increases with light intensity (Chalker 1981, Falkowski \& Dubinsky 1981). As is evident from Figs. 3-7, while the trends of all photosynthetic parameters in relation to photoacclimation are in full agreement with published data, our range in most cases is larger than that previously published, since we succeeded in including extremely low irradiance conditions, documented here for the first time.

The photosynthetic performance of Stylophora pistillata under dim light is bound to stem from the photoacclimation of the algae that combines coordinated ultrastructural, biochemical, and biophysical adjustments resulting in immensely improved light harvesting and utilization. Deep-water $S$. pistillata are almost black compared to the ivory-colored shallow water ones (Fig. 10), indicating that very few photons are indeed lost by reflectance (Falkowski \& Dubinsky 1981).

Working with Montastrea annularis, Dustan (1982) found a depth-dependent decrease in zooxanthellae densities from $8.76 \times 10^{6} \mathrm{~cm}^{-2}$ at $1 \mathrm{~m}$ to $2.65 \times 10^{6} \mathrm{~cm}^{-2}$ at $45 \mathrm{~m}$, a trend also reported by Titlyanov et al. (2001). However, Dustan (1982) and Titlyanov et al. (2001) also found cases where areal chlorophyll increases with
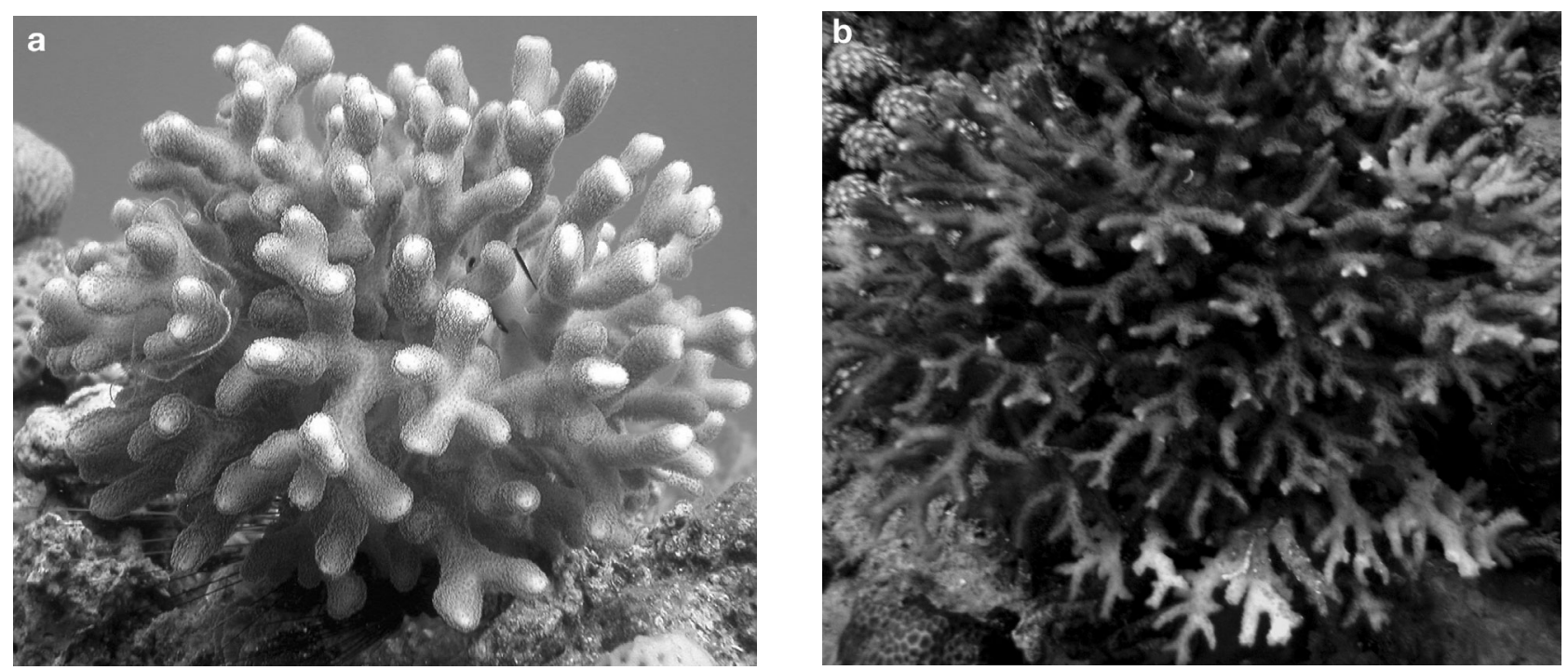

Fig. 10. Stylophora pistillata. Colony morphology. (a) Shallow-water colonies are subspherical and whitish. (b) Deep water colonies are planar, with the upper part dark, while the bottom-facing part is pale 


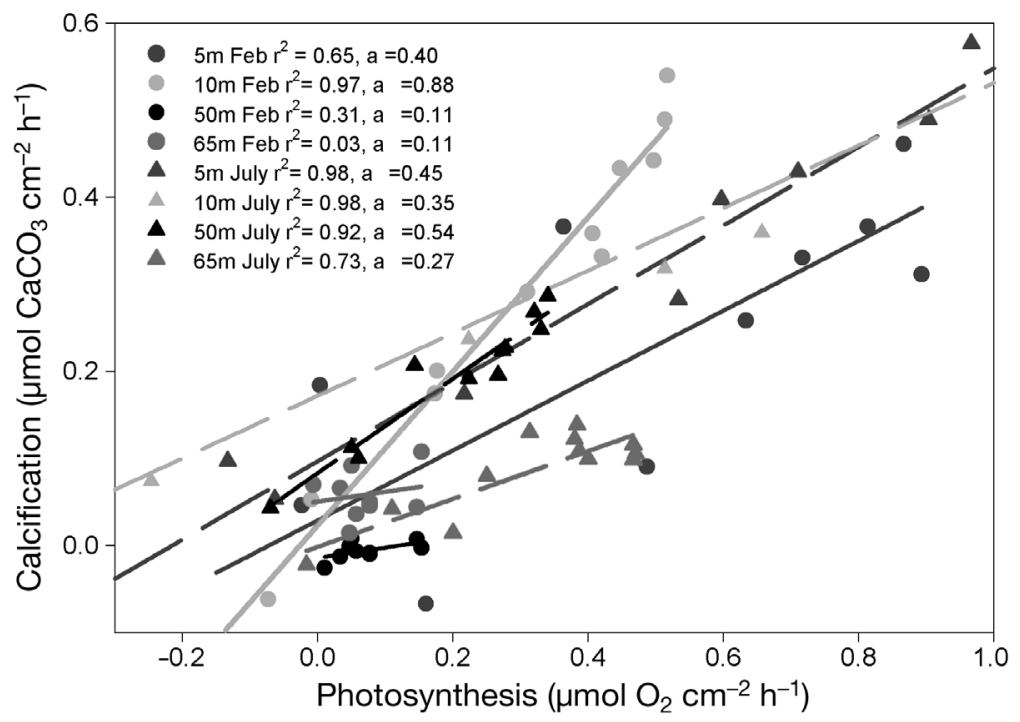

Fig. 11. Stylophora pistillata. Net calcification $\left(\mu \mathrm{mol} \mathrm{CaCO}_{3} \mathrm{~cm}^{-2} \mathrm{~h}^{-1}\right)$ as a function of net photosynthesis $\left(\mu \mathrm{mol} \mathrm{O} \mathrm{O}_{2} \mathrm{~cm}^{-2} \mathrm{~h}^{-1}\right)$ during the day, at depth gradients in winter (solid lines) and summer (dashed lines) $(\mathrm{n}=3)$
In this study, zooxanthellae density varied between seasons, being higher during winter and lower in summer. Superimposed on this, there was a depth-dependent density gradient in each season: one at 5 to $15 \mathrm{~m}$ depth and a different one at 20 to $65 \mathrm{~m}$ depth. In general, chl a concentrations increased as light decreased both with depth and season. This was evident with increased chl a concentrations at depths of $\sim 54 \%$ in summer and $\sim 76 \%$ in winter, and in winter compared to summer of $15 \%$ and $65 \%$ at 5 and $20 \mathrm{~m}$, respectively (Fig. 1). Daniel (2006), working at the same study site, showed a clear zonation pattern of zooxanthella cladal distribution in the Stylophora pistillata population: subclade A1.2 (shallow reef, 1 to $10 \mathrm{~m}$ ), C72 (mid-depth, 20 to $30 \mathrm{~m}$ ), and ITS types C21s, C21t, C1s, and C72s (deep reef, $>50 \mathrm{~m}$ ).

depth, to a limit where it falls off sharply due to a decrease in symbiont density. Dubinsky \& Jokiel (1994) reported that below a given threshold of light intensity, which in the case of $S$. pistillata is $\sim 0.5 \%$ of the surface intensity, there is not enough light to sustain the zooxanthellae, and the coral branches are white and hardly absorb any light. In our case, no such trend was evident; however, in our region, such light intensity is expected to occur only at 140 to $240 \mathrm{~m}$.

Dinoflagellates in general and zooxanthellae in particular (Dubinsky \& Jokiel 1994) display an increased chl a concentration per cell in the process of acclimation to low-light intensity (Falkowski \& Dubinsky 1981, Dubinsky et al. 1984), a universal response also found in free-living phytoplankton (Dubinsky et al. 1986). In nature, algal density in several corals varies around $1 \times$ $10^{6}$ cells $\mathrm{cm}^{-2}$ (Dubinsky et al. 1990); however, depending on light, eutrophication, and coral species, densities between $1 \times 10^{5}$ and $3 \times 10^{6}$ cells $\mathrm{cm}^{-2}$ have been reported (Dubinsky et al. 1990). Seasonal variation in cell density and tissue biomass has also been reported (Warner et al. 2002, Chen et al. 2005).

In most cases, acclimation of the holobiont (Kinzie et al. 2001) can be achieved by a change in the photophysiological traits of the symbionts, e.g. changes in pigment concentrations and ratios, Rubisco levels, and quantum yields of photosynthesis (Stambler \& Dubinsky 2004) or a switch of symbionts (Fautin \& Buddemeier 2004). These symbiont processes are complemented by physiological changes in the host, including lowered respiration and increase in anti-oxidant enzyme concentration (Levy et al. 2006).
LaJeunesse (2001) showed that the different clades have their own characteristic photoacclimatory responses to changes in irradiance. Our results support this claim, and the 2 trends in chl a concentration with depth (Fig. 1) might fit a clade change as reported by Daniel (2006). Under all but the lowest light intensities, there was a tight correlation between photosynthesis and calcification, firmly supporting Goreau's (1959) paradigm of 'light enhanced calcification.' However, a striking result emerged from our deepest samples: under the severely limited light in winter at 50 and $65 \mathrm{~m}$, photosynthesis no longer supported calcification (Fig. 11). This indicates that at great depth during winter, photosynthesis - in conjunction with a significant subsidy from predation - can barely satisfy the basic metabolic requirements (Dubinsky \& Jokiel 1994). Hence, deep corals require an external food supply for skeletal growth. One should note that in our experiments, corals were subject to light conditions similar in intensity (over the entire PAR range) but different in spectrum compared to the conditions existing in deep waters. It is possible that the deep-water corals are better adapted to function at this narrow spectrum. Likewise, it is possible that the narrow light spectrum of the deep changes the correlation in activity rate between the algal Photosystems II and I and lowers the overall energy/carbon availability. These possibilities require further studies entirely performed at depth. Our finding that at the lowest irradiance levels there was no correlation between photosynthesis and calcification seems to contradict our data that invariably show a clear light enhancement of calcification by light at these same 
irradiance levels. This is evident when light and daytime calcification rates are compared. This inconsistency may be explained by either the lack of a significant correlation due to the low rates of both processes and the resulting scatter of data points, or to a catalytic, non-linear stimulation of calcification by light. Obviously, our current data cannot determine the underlying mechanism behind this phenomenon.

We examined photosynthesis and calcification over a daily cycle in summer and winter on a whole bathymetric distribution of the coral Stylophora pistillata. We conclude that the energy source for calcification in the shallow habitats comes from photosynthesis, while in the deeper sites, even though photosynthesis occurs, it cannot support the process of calcification, and the coral must rely on other sources of energy, such as predation. This phenomenon is much more pronounced in winter, when light intensity is lower. Even though photoacclimative changes made by corals inhabiting the deep reef significantly reduce the difference in available light at the depth limit of the distribution of $S$. pistillata, these are insufficient to provide the entire energy requirements of the coral.

Acknowledgements. We thank the staff of the Interuniversity Institute for Marine Sciences at Eilat, M. Benzion, D. Iluz, O. Levy, and N. Stambler for their help and support. The deep dives were supported by the Rufford Small Grant for Nature Conservation. Comments by several anonymous reviewers greatly improved this manuscript. This study was performed in accordance with regulations and guidelines set by the Israeli Natural Parks Authority.

\section{LITERATURE CITED}

Barnes DJ (1983) Profiling coral reef productivity and calcification using $\mathrm{pH}$ and oxygen electrodes. J Exp Mar Biol Ecol 66:149-161

Ben-Zion M, Dubinsky Z (1988) An on-line system for measuring photosynthetic characteristics via an oxygenelectrode. J Plankton Res 10:555-558

Brandt JK (1883) Über die morphologische und physiologische Bedeutung des Chlorophylls bei Thieren. Mitt Zool Stn Neapel 4:191-302

Bruno JF, Edmunds PJ (1997) Clonal variation for phenotypic plasticity in the coral Madracis mirabilis. Ecology 78: 2177-2190

Chalker BE (1981) Simulating light-saturation curves for photosynthesis and calcification by reef-building corals. Mar Biol 63:135-141

Chen CA, Wang AT, Fang LS, Yang YW (2005) Fluctuating algal symbiont communities in Acropora palifera (Scleractinia: Acroporidae) from Taiwan. Mar Ecol Prog Ser 295:113-121

Daniel A (2006) Niche adaptation of coral and its zooxanthellae over a depth gradient of 5-65 $\mathrm{m}$ in the Gulf of Eilat. MS thesis, Tel Aviv University

Dubinsky Z, Jokiel P (1994) The ratio of energy and nutrient fluxes regulates the symbiosis between zooxanthellae and corals. Pac Sci 48:313-324
Dubinsky Z, Falkowski PG, Porter JW, Muscatine L (1984) Absorption and utilization of radiant energy by light-and shade-adapted colonies of the hermatypic coral Stylophora pistillata. Proc R Soc Lond B 222:203-214

Dubinsky Z, Falkowski PG, Wyman K (1986) Light harvesting and utilization in phytoplankton. Plant Cell Physiol 27: 1335-1349

Dubinsky Z, Stambler N, Ben-Zion M, McClosky L, Falkowski PG, Muscatine L (1990) The effect of external nutrient resources on the optical properties and photosynthetic efficiency of Stylophora pistillata. Proc R Soc Lond B 239: $231-246$

Dustan P (1982) Depth-dependent photoadaption by zooxanthellae of reef coral Montastrea annularis. Mar Biol 68: $253-264$

Erez J (1978) Vital effect on stable-isotope composition seen in foraminifera and coral skeletons. Nature 273:199-202

Falkowski PG, Dubinsky Z (1981) Light-shade adaptation of Stylophora pistillata, a hermatypic coral from the Gulf of Eilat. Nature 289:172-174

Fautin DG, Buddemeier RW (2004) Adaptive bleaching: a general phenomenon. Hydrobiologia 530 (Spec Issue): 459-467

Freudenthal HD (1962) Symbiodinium gen. nov. and Symbiodinium microadriaticum sp. nov., a zooxanthella: taxonomy, life cycle, and morphology. J Protozool 9:45-52

Fricke HW, Vareschi E, Schlichter D (1987) Photoecology of the coral Leptoseris fragilis in the Red Sea twilight zone (an experimental study by submersible). Oceologia 73: 371-381

Goreau TF (1959) The physiology of skeleton formation in corals. I. A method for measuring the rate of calcium deposition by corals under different conditions. Biol Bull (Woods Hole) 116:59-75

Jeffrey SW, Humphrey GF (1975) New spectrophotometric equations for determining chlorophylls $a, b, c_{1}$ and $c_{2}$ in higher plants, algae and natural phytoplankton. Biochem Physiol Pflanz 167:191-194

Kinzie RA, Takayama M, Santos SR, Coffroth MA (2001) The adaptive bleaching hypothesis: experimental tests of critical assumptions. Biol Bull (Woods Hole) 200:51-58

LaJeunesse TC (2001) Investigating the biodiversity, ecology, and phylogeny of endosymbiotic dinoflagellates in the genus Symbiodinium using the ITS region: in search of a 'species' level marker. J Phycol 37:866-880

Levy O, Dubinsky Z, Schneider K, Achituv Y, Zakai D, Gorbunov MY (2004) Diurnal hysteresis in coral photosynthesis. Mar Ecol Prog Ser 268:105-117

Levy O, Achituv Y, Yacobi YZ, Stambler N, Dubinsky Z (2006) The impact of spectral composition and light periodicity on the activity of two antioxidant enzymes (SOD and CAT) in the coral Favia favus. J Exp Mar Biol Ecol 328:35-46

Loya Y (1976) The Red Sea coral Stylophora pistillata is an $r$ strategist. Nature 259:478-480

Masuda K, Goto M, Maruyama T, Miyachi S (1993) Adaptation of solitary corals and their zooxanthellae to low light and UV radiation. Mar Biol 117:685-691

Muscatine L (1990) The role of symbiotic algae in carbon and energy flux in reef corals. In: Dubinsky Z (ed) Coral reefs. Elsevier, Amsterdam, p 75-87

Rosenfeld M, Yam R, Shemesh A, Loya Y (2003) Implication of water depth on stable isotope composition and skeletal density banding patterns in a Porites lutea colony: results from a long-term translocation experiment. Coral Reefs $22: 337-345$

Rowan R (1998) Diversity and ecology of zooxanthellae on coral reefs. J Phycol 34:407-417 
Smith SV, Key GS (1975) Carbon dioxide and metabolism in marine environments. Limnol Oceanogr 20:493-495 Sokal RR, Rohlf FJ (1995) Biometry, 3rd edn. WH Freeman, San Francisco, CA

Stambler N, Dubinsky Z (2004) Stress effects on metabolism of hermatypic coral. In: Rosenberg E, Loya Y (eds) Coral health and disease. Springer-Verlag, Berlin, p 195-215

Titlyanov EA, Titlyanova TV, Yamazato K, van Woesik R (2001) Photo-acclimation dynamics of the coral Stylophora pistillata to low and extremely low light. J Exp Mar Biol Ecol 263:211-225

Editorial responsibility: Howard Browman (Associate Editorin-Chief) Storebø, Norway
Trench RK, Blank RJ (1987) Symbiodinium microadriaticum Freudenthal, Symbiodinium goreauii sp. nov., Symbiodinium kawagutii sp. nov. and Symbiodinium pilosum sp. nov. - gymnodinioid dinoflagellate symbionts of marine invertebrates. J Phycol 23:469-481

Warner ME, Chilcoat GC, McFarland FK, Fitt WK (2002) Seasonal fluctuations in the photosynthetic capacity of photosystem II in symbiotic dinoflagellates in the Caribbean reef-building coral Montastraea. Mar Biol 141: $31-38$

Wells JW (1957) Corals. Geol Soc Am 67:1087-1104

Submitted: July 12, 2006; Accepted: November 19, 2006 Proofs received from author(s): February 22, 2007 